\title{
HERZEGOVINA REGION (BIH / RS): SETTLEMENT-DEMOGRAPHIC CHALLENGES OF SUSTAINABLE DEVELOPMENT
}

DOI: http://dx.doi.org/10.18509/GBP.2019.28

UDC: 314.114:330.34(497.6)

\section{Goran Mutabdzija}

Faculty of Philosophy, University of East Sarajevo, Pale, Bosnia and Herzegovina

\begin{abstract}
Bosnia and Herzegovina (hereinafter referred to as Bosnia and Herzegovina) is the first country in the world by the number of inhabitants who do not live in the country in which they were born [14] and, according to macroeconomic indicators, has the worst indicators in Europe $[6,13]$. In the territory of Republika Srpska (RS), one of its two entities, five regions can be distinguished [7]. The Herzegovina region is one of them, which has similar geographical problems throughout the territory. It has an unfavorable structure in all elements of economic and geographical development, and occupies $>1 / 3$ of the territory of the RS where $<1 / 6$ of the total population lives. In the domain of the demographic development of the RS [3], adverse trends are present, characterized by negative growth, very high medial age and uneven population distribution [4]. In the structure of the settlement, the absence of a strong gravitational center is noticed, but there are four sub regional centers [2], which with their demographic and economic strength do not satisfy the needs of the inhabitants of the whole region [11]. The complexity of the overall development of the Herzegovina region is complicated by inadequate economic activity and the level of infrastructure development. Based on these remarks, it is evident that the Herzegovina region represents a kind of paradigm of development throughout $\mathrm{BiH}$.
\end{abstract}

Keywords: Bosnia and Herzegovina (BiH), Republika Srpska (RS), Herzegovina region, sustainable development, rural-urban relations.

\section{INTRODUCTION}

The Herzegovina region is located in the southeastern part of the RS and does not represent a unique space in the physical-geographical, nor in the nodal-functional aspect. This feature is also the biggest problem of the sustainable development of this area, which with its complexity and weight exceeds the frames of the region itself. In economic terms, until 1992. this region was divided between the regions of Mostar and Sarajevo, and after the civil war, it is part of the RS entity. In the domain of local government, the region is divided into 20 municipalities, with the status of cities belonging to East Sarajevo and Trebinje. Because of the small number of inhabitants, and in order to satisfy the NUTS criteria, three different morphological and nodal-functional units are integrated into one [7]. The name of the region is the result of a compromise between the names of traditional historical regions and regional identities, so this is the only region of the RS whose borders are wider than the historical and geographical interpretation of the name itself. J. Dedijer (1909) also recognized that "there is a narrower and wider meaning of this term (ethnographic Herzegovina), with the worst inhabited part of the Republic of Srpska today and has the most complex relief structure. Therefore, the geographical problems of this 
part of the RS are very pronounced and significantly jeopardize the sustainability of the development of the entire RS" [7].

This is the largest region of the RS (38\%), which stretches from Sokolac to Trebinje. The borders of the region make the state border with Serbia and Montenegro in the east, with Croatia to the south, and in the west, the inter-entity border line (Federation of $\mathrm{BiH}$ ). In the north there is the neighboring Bijeljina region (RS). Three different morphological units can be distinguished within this area. The composite valley of the Upper Drina River $(122 \mathrm{~km})$ forms the axis of the sub-region of Gornje Podrinje, within which the most important are the Foča and Visegrad basins. The second sub region is made up of the Sarajevo-Romanija region, which consists of cascadingly arranged three morphological units: the Sarajevo field (altitude $500 \mathrm{~m}$ ), the Romanija plateau $(800-900 \mathrm{~m})$ as part of wide area the Stari Vlah plateau and mountains: Trebevic (1629), Jahorina (1913), Romanija (1629) and Treskavica (2088). The third sub region is made up of the historical province of Herzegovina, which in geotectonic terms coincides with the area of the outer Dinarides (High karst zone and Durmitor cover) and from the neighboring sub regions in the north separated by the high ridge of Maglic (2386), Volujak (2228), Zelengora (2103) and Lelija (2103). In the hydrographic view, this is the catchment area of the Neretva on the territory of the RS, characterized by its specific karst swelling. Within this sub region, there are numerous karst forms, with karst fields being especially interesting. They descend from the north to the south successively and cascading, they stand out: Nevesinje (860 m), Gacko (840), Dabar (470), Fatnica (460) and Popovo field (270).

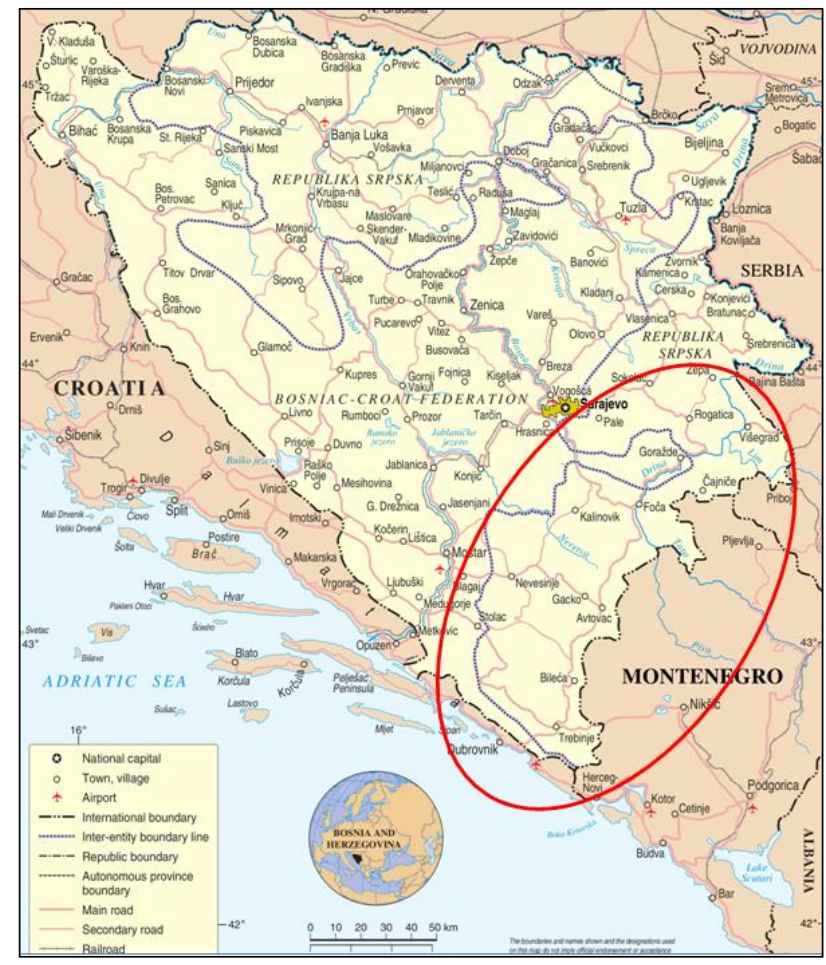

Figure 1. Herzegovina region within $\mathrm{BiH} / \mathrm{RS}$

Source: Wikimedia

On the basis of this, it is evident that this is not a unique space in the physio-geographical, nor in the nodal-functional aspect. The complexity of these problems is inherited from the past and cannot be eliminated on the basis of short-term solutions. Structural problems are related to the reduction of the number of inhabitants, its uneven distribution, 
irregularities and weaknesses in the system of urban settlements, inadequate infrastructure, and above all, the low level of total economic activity [9].

\section{DEMOGRAPHIC PROCESSES}

One of the great problems that hampers the sustainable economic development of the Herzegovina region is certainly demographic development. Problems are visible in almost all of its aspects, from the number, location and density of the housing to vital statistics and migration.

Table 1. Basic indicators of the sub regional entities of the Herzegovina region

\begin{tabular}{lccccccc}
\hline \multirow{2}{*}{$\begin{array}{c}\text { Sub regions / urban } \\
\text { subsystems }\end{array}$} & $\begin{array}{c}\text { Area } \\
\left.\mathbf{( k m}^{2}\right)\end{array}$ & \multicolumn{2}{c}{ No. of inhabitants } & \multicolumn{2}{c}{$\begin{array}{c}\text { Inhab. per } \\
\mathbf{k m}^{\mathbf{2}}\end{array}$} & \multicolumn{2}{c}{$\begin{array}{c}\text { No. of } \\
\text { settlements }\end{array}$} \\
\cline { 3 - 9 } & 2.475 & 67.800 & 61.516 & 45 & 41 & 353 & 329 \\
\hline Sarajevo -Romanija region & 3.048 & 86.832 & 57.683 & 24 & 16 & 520 & 411 \\
\hline Gornje Podrinje & 3.866 & 76.491 & 67.838 & 20 & 18 & 370 & 327 \\
\hline Herzegovina & 9.389 & 231.123 & 187.037 & 26 & 21 & 1.243 & 1.067 \\
\hline Total & & & &
\end{tabular}

Source: Statistical Office [15].

This region represents $37.8 \%$ of the total area of the RS, with 1067 settlements in which only $15.7 \%$ of the population of the RS lives. The density of housing is 21 inhabitants per square $\mathrm{km}$, which represents only $43.8 \%$ of the average value for the RS.

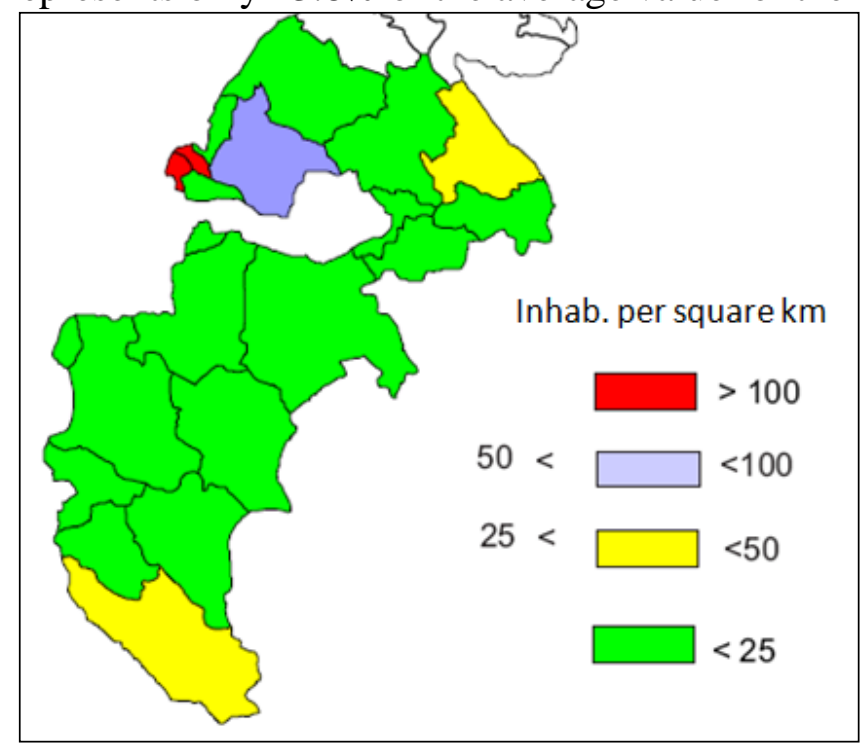

Figure 2. Density of housing per municipality of Herzegovina region [5].

The ultimate disadvantage of such a demographic reality is mostly reflected in underdeveloped, mainly mountainous areas, where the intensity of economic activity is significantly reduced. There are 187,037 inhabitants in this region. Indicators of vital statistics indicate that there is a long negative effect on the territory of the entire RS for various factors, ranging from socio-economic, biological, psychological to sociopolitical, which to a varying extent affect the constant decline in birth rates and negative natural increase [10].

The results of the last population census (2013) show that the RS, according to the general rate of birth rate $(8.1 \%)$, has characteristics of an extremely low-grade area. The change in biological structures influenced the aging of the population, which led to increased 
rates of mortality and negative rate of natural change (-3.8 \%o). Within the Herzegovina region, these indicators show even more negative results.

Table 2. Demographic statistics indicators for selected municipalities 2013

\begin{tabular}{|c|c|c|c|c|c|c|c|}
\hline \multirow[b]{2}{*}{$\begin{array}{c}\text { Elements of demographic } \\
\text { statistics }\end{array}$} & \multirow[b]{2}{*}{$\mathbf{R S}$} & \multicolumn{3}{|c|}{ Positive examples } & \multicolumn{3}{|c|}{ Negative examples } \\
\hline & & Trebinje & Pale & $\begin{array}{l}\text { Ist. N. } \\
\text { Saraj. }\end{array}$ & $\begin{array}{c}\text { Is. } \\
\text { St.Grad }\end{array}$ & Kalinovik & Višegrad \\
\hline General Birth Rate (\%o) & 8,1 & 8,5 & 8,0 & 9,5 & 4,4 & 6,1 & 4,4 \\
\hline General Mortality Rate (\%) & 11,9 & 11,8 & 11,2 & 13,2 & 23,8 & 23,8 & 14,8 \\
\hline The rate of natural change (\%o) & $-3,8$ & $-3,3$ & $-3,2$ & $-3,8$ & $-19,4$ & $-17,8$ & $-10,4$ \\
\hline Natural Change 1996-2016 (\%) & $-4,0$ & $-2,2$ & $-5,9$ & $-4,8$ & $-30,1$ & $-28,9$ & $-15,2$ \\
\hline Intern. migration bal. 2007-16. & - & 632 & 590 & 2704 & 39 & -91 & -378 \\
\hline Change no. inh. 1991-13(\%) & -25 & -3 & 41 & 157 & -18 & -54 & -52 \\
\hline Av. age of the population & 41,72 & 42,20 & 41,70 & 40,31 & 48,08 & 48,27 & 44,92 \\
\hline Av. members of the household & 2,85 & 2,99 & 2,83 & 2,71 & 2,55 & 2,50 & 2,51 \\
\hline
\end{tabular}

Source: Statistical Office [15].

Spatial distribution of the population is the starting point for determining the functional sustainability of the development of each territory. Considering the specificity of this distribution in the horizontal view (Map 2), as the average density of dwellings per municipality, it indicates increased values in the marginal parts of the region (Istocno Sarajevo, Visegrad and Trebinje) and very low in the central parts of the region (all other municipalities). Through the analysis of hypsometric relations it is also possible to consider the other component (vertical) distribution of population in height zones.

Table 3. Population distribution in height (hypsometric) zones

\begin{tabular}{|c|c|c|c|c|c|c|}
\hline \multirow{3}{*}{ Height belt (m) } & \multicolumn{5}{|c|}{ Republika Srpska } & \multirow{3}{*}{$\begin{array}{c}\text { Herzegovina Region } \\
\text { Municipal Centers }\end{array}$} \\
\hline & \multicolumn{2}{|c|}{ Area } & \multicolumn{2}{|c|}{ Population } & \multirow{2}{*}{ Inh. / km² } & \\
\hline & $\mathrm{km}^{2}$ & $\%$ & No. & $\%$ & & \\
\hline$<200$ & $4.389,8$ & 17,7 & 473.587 & 40,4 & 108 & - \\
\hline $201-500$ & $6.752,7$ & 27,4 & 476.855 & 40,8 & 71 & Visegrad, Rudo and Trebinje. \\
\hline $501-1000$ & 7.098 & 34,2 & 190.007 & 16,2 & 27 & All other municipalities \\
\hline$>1000$ & $14.731,8$ & 20,7 & 29.893 & 2,6 & 2 & - \\
\hline Total & $24.640,3$ & 100 & 1.170 .324 & 100 & 47,5 & \\
\hline
\end{tabular}

These indicators have a fundamental significance for a more detailed analysis of the spatial distribution of the population. In the example of the Sarajevo-Romanija region, which makes up $1 / 4$ of the Herzegovina region, where $1 / 3$ of the population lives, this component has shaped the spatial-functional relations of the past. With the knowledge of the structure of the land fund, and with the application of the CORINE methodology, it is evident that "the largest area occupies forests (52.54\%), agricultural land group III (33.97\%), group II (9.13\%), group I $3.41 \%)$ and arid land-cities $(0.96 \%)$. This analysis should also include the analysis of the hypsometric relationships, ranging from $290 \mathrm{~m}$ to $1900 \mathrm{~m}$, in order to better understand the physiognomic structure of this region. Fields up to $500 \mathrm{~m}$ occupy only $1 \%$ of the total area of the region, terrain height $500-800 \mathrm{~m}$ is $17 \%$, land of 800 to $1200 \mathrm{~m} 66 \%$, and terrains over $1200 \mathrm{~m}$ make $16 \%$. The average altitude of the region is $990 \mathrm{~m} "$ [8].

\section{NODAL-FUNCTIONAL RELATIONS}

The issue of urbanization is another important issue in the domain of the treated issues. In the domain of urban-rural relations, within the region there are 1067 settlements, out 
of which only 11 settlements with over 5000 inhabitants have elements of urbanization. The percentage of urbanization is $58.3 \%$, and the largest urban centers are: Trebinje, Pale, Foča, Istočna Ilidža, Istočno Novo Sarajevo, Bileća, Rogatica, Višegrad, Gacko, Sokolac and Nevesinje. In the domain of the hierarchy of settlements, the most numerous are the small settlements with fewer than 200 inhabitants and they account for $90 \%$ of all settlements. Basically, besides the municipal center, there are only the smallest settlements, which mean that the process of depopulation in the municipalities is strongly expressed and that only a small number of older inhabitants in the small rural settlements remain. This is confirmed by the ratio of the population of the municipal center and the total population of the municipality. The most unfavorable situation is in Trebinje, where $87.6 \%$ of the total population is concentrated in the municipal center, in Istocno Novo Sarajevo it is $80.4 \%$ and in Bileca $76 \%$. Nevesinje (42.1\%), Sokolac (49.2\%) and Višegrad (55\%) have the most favorable spatial distribution of the population on the territory of the entire municipality.

This unevenness of the population distribution within the local community clarifies the Gini-coefficient that represents the relationship between the surfaces that makes the curve of uniform distribution and the fault of the concentration of the population. The complete regularity of the distribution of the population is the amount of 0 Gini-coefficient, and with the increase in the difference index value goes up to a maximum of $1(100 \%)$. For the Republic of Srpska, the value of this index is 0.6, while the most unfavorable amount in the Herzegovina region is Trebinje is 0.92 [1].

In addition to the very unfavorable demographic characteristics and existing trends in the area of population growth and development, the Herzegovina region has a very complex network of settlements. It is manifested by the absence of a functional and hierarchical network of urban and developing centers. When it comes to the size of certain urban systems that exist within these sub regional units, there are differences and they are further enhanced by the absence of quality infrastructure connections between them. From the very notion of the nodal region it follows that it is a space that makes the functional unity of the city and the surrounding area, which is achieved through constant interaction in the domain of circulation of people, goods and information. This area is very heterogeneous in terms of natural geographic characteristics, degree of economic development and level of urbanization, and the principle projections of the conditionally nodal system of this region are based on estimates. At its core (horizontal dimension) is the system of urban centers (city and municipal centers) with the corresponding network of settlements of lower taxonomic rank (secondary municipal centers and rural settlements), which build three conditional urban subsystems, equivalent to existing sub regional units (SarajevoRomanija, Gornje Podrinje and Herzegovina).

In the domain of hierarchy of urban centers (vertical dimension), based on which the number of small centers can be seen functionally depends on the center of the higher rank, three levels can be identified. The first level is represented by four sub regional centers which, with its size and gravity force, is the basis for the future differentiation of a mesoregional center, and this group includes: Trebinje, Foča, Pale and the double center Istocno Novo Sarajevo / Istočna Ilidža. These centers have a peripheral position, except for Foča, which is the smallest demographic and weakest in functional terms, which will make it difficult to construct the vertical structure of the settlement network. The second level is represented by ten municipal centers. Their total number is approximate in each sub region, but there are also large demographic differences between them. The third level is represented by secondary municipal centers, which are not clearly differentiated and 
often represent the centers of the village community. This group includes four municipal centers (Istocni Mostar, Berkovici, Novo Gorazde and Istocni Stari Grad) which do not have adequate elements of urbanity with their size and level of infrastructure.

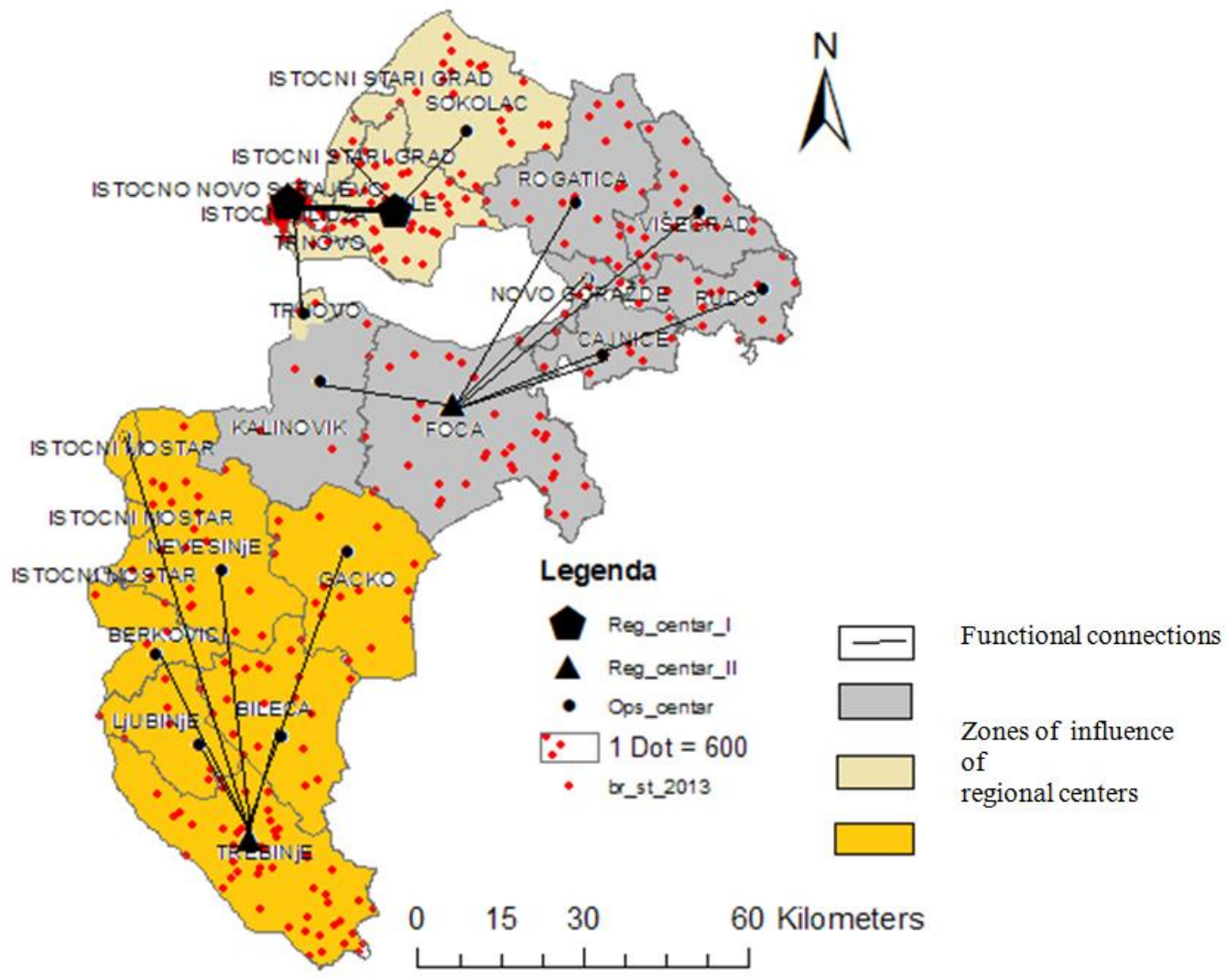

Figure 3. Nodal-functional relations and hierarchy of settlements within the Herzegovina region

The absence of the main node for this conditionally nodal region indicates the characteristics of the underdeveloped area, and it is possible to speak of the existence of elements of an irregular vertical hierarchy of urban centers. The analysis of the spatial or horizontal dimension of these urban subsystems starts from the number of municipal centers, which are seven in both regions, the Sarajevo - Romanija in Herzegovina, and six in Gornje Podrinje region. In addition to their number and conditional size, the gravitational area of these subsystems is equal. Given the migrations inside and outside these areas, it is clear that these are economically inactive spaces within which only the local movements have greater dynamics. Given the position of urban centers, the density of housing, the total number of settlements and the intensity of movement, the region is dominated by asymmetric urban subsystems with irregular characteristics, which are characteristic of insufficiently developed spaces. Based on urban-rural relations in Sarajevo - Romanija region, we can recognize three different zones: the dominant urban, transitional type from rural to urban and dominantly rural type of local communities. The municipality of East Ilidža-East-Novo Sarajevo is an example of a typical urban community characterized by the compactness of the architectural and urban complex with a density of 424 inhabitants per $\mathrm{km} 2$, a concentration of $35 \%$ of the population of the region, an average altitude of $<600 \mathrm{~m}$, near Sarajevo, the existence of institutions of varying degrees of importance and numerous content of the service sector. The municipality of Pale represents the second entity dominated by mountain relief, the 
average altitude is $>900 \mathrm{~m}, 29 \%$ of the population lives in the municipality, a network of settlements is developed in which the municipal center dominates all elements of the spatial structure. The presence of institutions of republic and regional significance and proximity to Sarajevo $(22 \mathrm{~km})$ intensifies the nodality of this center, but low density of housing ( $45 \mathrm{st} / \mathrm{km} 2$ ) places this municipality in a transitional type. The rest of the region includes 4 underdeveloped municipalities with dominant mountain relief (average altitude> $1000 \mathrm{~m}$ ), in which $36 \%$ of the region's population lives with an average living quarters of $17 \mathrm{st} / \mathrm{km} 2$. It is clear that this area has dominant rural characteristics [7].

Based on the indicators, the Sarajevo - Romanija region represents an increasingly less fluid space between urban and rural, and more a place with a vision of future development. The degree of development of this area over the last two decades has been dynamic and has managed to mitigate the negative effects of the recent past through a parallel process of population concentration and institution building. The intensity of urbanization is cascading and proportionally decreasing with the distance from Sarajevo, which is evident through the existence of three different zones, which give the entire region characteristics of the transitional urban-rural entity. In this way, the hypotheses of work have been confirmed by which the lack of urban content and economic activity leads to the weakening of nodal-functional connections within the region, economic stagnation and the process of depopulation of rural areas (Sokolac, Rogatica, East Stari Grad and Trnovo), as well as strengthening education and health institutions and economies, represents the most efficient measures in order to increase the urban level of the whole region, which positively influences the increase of cohesion within the region (Istočna Ilidža, Istočno Novo Sarajevo and Pale).

\section{CONCLUDING CONSIDERATIONS}

The Herzegovina region is the most poorly inhabited part of the RS, which also has an unfavorable structure of the settlement network and an inadequate economic base. The difficulty of sustainable development is enhanced by the complexity of the relief structure and, consequently, the traffic infrastructure. Therefore, the sustainability of the development of this part of the RS is questionable and significantly jeopardizes the sustainability of the development of the entire Republika Srpska. The complexity of these problems is inherited from the past and cannot be eliminated on the basis of short-term solutions. Structural problems are related to the reduction of the number of inhabitants, its uneven distribution, irregularities and weaknesses in the system of urban settlements, inadequate infrastructure, and above all, the low level of total economic activity. All of these factors lead to the creation of a broad demographic depopulation zone (exodus zone) characterized by the sub-prime density of the dwelling and predominantly agrarian activity. Because of this, this region shares the fate of a wider mountainous-valley area, characterized by marked depopulation, negative natural increase, demographic aging and a negative migration balance.

The solution of such negative demographic-settlement trends implies the existence of a clear awareness of their weight and scope, and then, a clear vision of the long-term process of their overcoming. The economic growth and development of the entire the RS should be the primary goal, and after that a clear policy of regional development, based on the real sources and political consensus of the main actors in the Republic of Srpska. For the success of this process, integration processes in the Western Balkans will be crucial and creating a wider zone of economic stability and high rates of economic growth. 


\section{REFERENCES}

[1] Marinković, D., Majić, A. Stanovništvo Republike Srpske - demografski faktori i pokazatelji. Bosnia and Herzegovina, 2018.

[2] Mutabdzija, G. Jugoistok Republike Srpske - geografski problemi. Nauka i identitet, Bosnia and Herzegovina, vol. 6 (2), pp. 741-750, 2011.

[3] Mutabdzija, G. Demografske karakteristike Istočnosarajevsko-zvorničke regije. Demografska stvarnost Republike Srpske 1992-2012. Bosnia and Herzegovina, vol. 30, pp. 127-137. 2012.

[4] Mutabdzija, G. Evropski izazovi - od geogrfaskih ka inovativnim regijama. Bosnia and Herzegovina, 2016.

[5] Mutabdzija, G. Ekonomski identitet i naseljska stvarnost Republike Srpske. Godišnjak Matice Srpske - Društvo članova Matice u Republici Srpskoj, vol. 7, Bosnia and Herzegovina, pp. 367379, 2017.

[6] Mutabdzija, G. Regional geography of Europe. USA, 2018.

[7] Mutabdzija, G. Regionalna geografija Bosne i Hercegovine. Bosnia and Herzegovina, 2018.

[8] Urbanistički zavod RS Prostorni plan Grada Istočno Sarajevo. Bosnia and Herzegovina, 2004.

[9] Urbanistički zavod RS Prostorni plan Republike Srpske do 2025. Bosnia and Herzegovina, 2015.

[10] Tanović, M., Marinković, D. Urbana i ruralna naselja na prostoru Grada Istočno Sarajevo, Bosnia and Herzegovina, Herald, vol. 8 (22). pp. 49-60, 2018.

[11] UNDP BiH. Regional Disparity Assessment in Bosnia and Herzegovina, 2010.

[12] Vlada RS. Strateški plan ruralnog razvoja Republike Srpske 2009-2015. Bosnia and Herzegovina, 2009.

[13] htps://tradingeconomicscom/country-list/unemployment-rate?continent.europe.

[14] http://www.pewresearch.org

[15] http://www.rzs.rs.ba 